\title{
Luis Salvador Jaramillo. El cuervo decapitado. Loja: Casa de la Cultura Ecuatoriana de Loja,
}

2013.

El único sobreviviente del fin del mundo frente al vigía del faro de los confines de la tierra, un duelo desigual con un final inesperado. Con este aperitivo, comienza el ecuatoriano Luis Salvador Jaramillo Idrobo (Loja, 1955) el libro de cuentos El cuervo decapitado donde el suspense y el enigma, donde el temor y el temblor están presentes desde la primera hasta la última de sus páginas. Dividida en cuatro apartados, que aglutinan los relatos según su eje narrativo, esta nueva entrega del escritor ecuatoriano apuntala su trayectoria, sustentada en obras como la novela El antifaz de los Bristol (Libresa, 2012) y los volúmenes de cuentos En el secreto de los sueños (Casa de la Cultura Ecuatoriana de Loja, 2006) El sótano y otros cuentos (Casa de la Cultura Ecuatoriana de Loja, 2010), Bajo las aguas (Casa de la Cultura Ecuatoriana de Loja, 2011) y el premiado Lo que el diablo se olvidó de llevar (Casa de la Cultura Ecuatoriana de Loja, 2014). En 2017, Luis Salvador Jaramillo ha publicado las novelas El buen rey y El espiritu del desierto, así como el libro de cuentos Los territorios del lobo, además de alguna reedición de sus libros anteriores, por lo que ha sido un año muy fructífero para el escritor lojano.

Ambientadas en diferentes épocas, ubicadas en numerosos lugares, las historias de Luis Salvador Jaramillo nos hablan de venganzas servidas en plato frío con la fantasía como aderezo, de miedos y traiciones, de secretos malignos y personajes perniciosos: los protagonistas pagan caro su confianza en aquello que les rodea, sufriendo finales cruentos que sacudirán al lector, generando desconciertos y sobresaltos.

Primero Ariel, después el cosmos. En «Meridión», el espíritu de las siete cabezas merodea en busca de víctimas para usar su cuerpo como arma para la destrucción total. ¿Será el teniente Stanley Butler su víctima? En "La gran impostura», degustamos una venganza fría como el agua de un pozo, con el miedo como seńuelo y la mentira como estratagema, una narración de excesos y riquezas, de conquista y aniquilación, de mensajes con doble sentido y de traiciones. Una araña y una avispa, una trampa heredada, una tela que reduce y atrapa al protagonista del cuento "La avispa en la telaraña», quien se deja reducir y atrapar, porque ya nada será como antes, ya no hay vuelta atrás en la casa de Irina.

En «El visitante» no interesa tanto cuál es el final, sino cómo se llega a él y en "Trescientos sesenta y cinco», un rey con miedo a morir aprende a vivir de manos de aquel que mucho ha vivido, aunque no sea un sabio de su corte. En «El guardián que veía los corazones», la bondad del monje Hilarión y su poder para leer los corazones le depara probar los sinsabores de la credulidad, pero también la dulce recompensa de la compasión.

En «El anillo del cadí», un platero y un juez entrecruzan sus vidas para descubrir demasiado tarde que los engaños constantes pueden traer funestas consecuencias para la permanencia de sus cabezas en el cuerpo. «La piedra maravillosa» narra la curiosa manera que elige un rey para escoger al príncipe heredero y esposo de su hija, pero el lector tiene que sobreponerse no sólo a los vertiginosos acontecimientos, sino a las dudas de sus protagonistas y del propio narrador. "Dante el herrero» es el cuento de una renuncia, del trueque de felicidad por fama y «El mayordomo leal» es la historia de un joven desahuciado por la vida, que encuentra trabajo como mayordomo en una casa, la cual provoca una fascinación por una identidad oculta y una truculenta familia con unas peligrosas prácticas para ganar dinero.

«Una decisión difícil» es la descripción de un atrevido acto por amor en un ambiente desangelado, de cómo un noveno escalón puede cambiar la vida de los inquilinos de un edificio y de un joven, que encontrará en la escritura su tabla de salvación. «La reina» es la andanza de un alumno brillante a su pesar y maltratado en el colegio, que tiene que escoger una madrina para el equipo de fútbol del centro 
educativo y cómo implanta una caballerosa moda de la forma más insospechada.

En «Bajo las aguas», las obras de una presa obligan al protagonista a un periplo por un valle de manos de Santos, el cicerone del lugar con una singular capacidad para saber si los moribundos pueden esquivar a Cerbero; un paseo bajo un sol de justicia en busca de las últimas familias de la zona, pero lo que va a encontrar es un acervo de historias fatídicas y siniestras y una obsesión. «El cuervo decapitado» es la historia de unos diamantes, de un pueblo pequeño, de una venta frustrada, de una desoladora celda y la aventura más importante que Juan va a vivir, en la que va a ver pasar la muerte por delante de sus ojos, pero sobre todo va a tener la oportunidad de recuperar la felicidad perdida, tal vez para siempre.

En «Rap de la casa junto al fresno», nada es lo que parece. Tres trillizos, tres amantes para una mujer, tres identidades como barajas en una partida de naipes, en donde cada cual usa la cartas de los nombres y sus semejanzas para su propio beneficio, sin importar nada ni nadie, ni siquiera el fresno, ni tan solo el cadáver en la casa. En «La mujer de hotelito barato", un administrador de hotel asiste a un supuesto asesinato y pone todo su empeño en averiguar la verdad, pero sin darse cuenta de que puede ser la próxima víctima de la mujer del hotelito barato. «Mr. Freeman educa a un joven y talentoso caníbal» es el episodio de un fracaso a partir de un descubrimiento insólito y en «El fin», el último relato del volumen, tres personajes, dos balas, un disparo y un final misterioso para un duelo sin cuartel y sin testigos inoportunos. Al lector le espera una lectura emocionante durante la que deberá estar atento para anticipar el desenlace de cada historia y no dejarse sorprender por un narrador hábil en el desarrollo de los argumentos e inquietante en los finales.

Carlos Ferrer

Academia de Artes Escénicas de España 